\title{
Wood anatomical responses of oak saplings exposed to air warming and soil drought
}

Patrick Fonti ${ }^{1}$, Olivier Heller $^{1}$, Paolo Cherubini ${ }^{1}$, Andreas Rigling ${ }^{1}$, Matthias Arend ${ }^{1}$

\footnotetext{
${ }^{1}$ Swiss Federal Research Institute for Forest, Snow and Landscape Research WSL, Zürcherstrasse 111, CH-8903 Birmensdorf, Switzerland.
}

Corresponding author:

patrick.fonti@wsl.ch, phone: +41 4473922 85; Fax: +41 447392285

Short title: Wood anatomical responses to warming and drought

Keywords: xylem anatomy, water conducting cells, xylem hydraulics, 20 phenotypic plasticity, drought tolerance. 


\section{Abstract}

Water is vital for plant performance and survival. Its scarcity, induced by a seasonal decline in soil water availability or an increase of evaporative demand, can cause failures of the water conducting system. An adequate tolerance to drought and the ability to acclimate to changing hydraulic conditions are important features for the survival of long-lived woody plants in dry environments.

In this study we examine secondary growth and xylem anatomical acclimation of 6 year old saplings of three European oaks species (Quercus robur, Q. petraea, Q pubescens) during 30 the third consecutive year of exposure to soil drought and/or air warming (from 2007 to 2009). Intra-annual pinning was applied to mark the development of the formation of the annual ring 2009. Vessel size, parenchyma cell density and fiber size produced at different time of the growing season 2009 were compared between drought and warming treatments and species. Drought reduced secondary growth and induced changes in xylem structure while air warming

35 had little effect on wood anatomical traits. Results indicate that drought-exposed saplings adjust their xylem structure to improve resistance and repairing abilities after cavitation. All species show a significant radial growth reduction, a reduced vessel size with diminished conductivity and a slightly increased density of parenchyma cells. Comparisons between species fostered our understanding of the relationship between the inter-specific xylem hydraulic plasticity and the ecological behavior to drought. The stronger changes observed for $Q$. robur and $Q$. petraea indicate a lower drought tolerance than $Q$. pubescens.

\section{Introduction}

Survival and performance of long-lived woody plants strongly depends on their ability to adjust their metabolic processes to the continuous and highly variable environmental conditions. From a broad perspective, there are two main strategies to cope with changes: species may adapt through genetic changes via the process of evolution, or acclimate by exploiting their range of phenotypic and physiological plasticity (Lambers et al., 2008). However, due to the 
unprecedented rate of climate change and relative little time for altering the genetic constitution, responses of long-lived plants have mainly to rely to their acclimation capacity (Sultan, 2000; Valladares et al., 2007). Acclimation processes, i.e., positive structural or physiological response to new conditions, usually take place over the course of weeks to years, and thus differ from the short-term physiological regulation.

Among the environmental factors expected to vary with global climate change, soil water

55 scarcity has been identified as the major factor affecting plant growth, development and productivity (IPCC, 2007). Drought is in fact an important stress factor and can lead to physiological and structural responses to maintain balanced water relations (Maherali and DeLucia, 2000; Arend and Fromm, 2007; McDowell et al., 2008; Eilmann et al., 2009; Martinez-Vilalta et al., 2009). To fix carbon and to grow, woody plants have to collect and

60 transport water from the soil up to the leaves where photosynthesis occurs (Hopkins and Hüner, 2008). Water evaporating from the leaf generates a negative tension which is transmitted downwards through continuous water columns to the root-soil interface (Zimmermann, 1983). This hydraulic pathway is vulnerable to breakage through the induction of cavitation, when conduits are under exceedingly high tension (Tyree and Zimmermann,

65 2002; Lambers et al., 2008).

To cope with drought induced hydraulic damages, trees have developed an array of mechanisms occurring at different time scales (Maseda and Fernandez, 2006). Stomatal closure is the fastest physiological process to limit transpiration preventing a critical decrease in water potential (Tyree and Ewers, 1991; Sperry et al., 2008; Zweifel et al., 2009). Xylem embolism under severe drought can also be avoided through long-term acclimation processes occurring through changes on the structural level. On one hand trees can limit their need for water by reducing transpiring leaf area (Rigling et al., 2010), or by increasing the accessibility to the water source by expanding the roots (Klein et al., 2011). On the other hand however, trees can also adjust their water transport system by making it more tolerant to cavitation, 75 which usually occurs at the cost of efficiency and performance (Sperry et al., 2008; McDowell, 2011). Tolerance to cavitation can be attained by i) increasing prevention against cavitation through a reinforced cell wall structure (Hacke et al., 2001; Domec et al., 2008); ii) increasing 
the capacity to actively refilling embolized conduits using starch related energy stored in parenchyma cells (Bucci et al., 2003; Zwieniecki et al., 2004; Salleo et al., 2009; Zwieniecki and Holbrook, 2009;); or by iii) increasing redundancy in water pathways (Ewers et al., 2007; Schenk et al., 2008). All the changes occurring at the xylem structural level are ultimately permanently and chronologically stored inside the anatomical tree-ring structure and can thus be retrospectively analyzed (Fonti et al., 2010).

Quercus robur, Quercus petraea and Quercus pubescens are three of the most important broad leaved species in Europe, growing mainly on sites with irregular soil water supply. Among them, however, in recent decades $Q$. robur is experiencing increased mortality in Europe (Thomas et al., 2002) which have been often associated with changes in water availability (Cochard et al., 1996; Tyree and Cochard, 1996; Siwecki and Ufnalski, 1998; Cater, 2003; Cater and Batic, 2006; Allen et al., 2010; Bergman et al., 2011). Although these oak species have similar wood structure, characterized by a clear ring porosity, there are some differences in their ecological behavior especially to drought. Q. robur is not exclusively restricted to drought prone sites, occupying also hydromorphic soils experiencing periodic flooding. This ecological difference indicates a higher requirement for water in $Q$. robur than in $Q$. petraea and $Q$. pubescens, which is well reflected by lower water use efficiency (Ponton 95 et al., 2002), higher sensitivity to decreasing soil moisture (Vivin et al., 1993) and lower stomatal responsiveness to decreasing air humidity (Gieger and Thomas, 2005). In contrast, Q. pubescens is commonly considered to be more tolerant to drought and heat, which is reflected in its main distribution area located in the warmer and dryer climates of the Mediterranean area in southern Europe.

100 We hypothesize that inter-specific differences in drought-tolerance might be related to a different capacity to acclimate to a safer hydraulic architecture when subjected to water stress. In this study, we analyzed i) xylem growth responses and ii) inter-specific acclimation differences in hydraulic-relevant xylem anatomical features in saplings of three oak species (Q. robur, Q. petraea and Q. pubescens) differing in their tolerance to drought. Saplings were 105 experimentally exposed to soil drought and air warming during three consecutive growing seasons (2007 to 2009) and compared with control sapling growing with regular water supply 
and ambient air temperature. Analyses consider differences in annual and intra-annual ring formation including growth and anatomical characteristics of vessels, parenchyma and fibers cells.

\section{Materials and methods}

\section{Experimental design and plant material}

The 48 oak trees analyzed in this study are part of the interdisciplinary "Querco" experiment studying provenance-specific responses of $Q$. robur, Q. petraea and $Q$. pubescens to drought and air warming. The origin of the provenances and the experimental design are described in detail by Arend et al. (2011). In brief, four provenances from each oak species were selected from natural forest stands in Switzerland and Italy, covering a wide range of environmental conditions. Three-year old saplings from each provenance were grown for three years (2007 - 2009) in 16 lysimeter-based open-top chambers of the model ecosystem facility of the Swiss

120 Federal Research Institute WSL, Birmensdorf, Switzerland (47²1'54"N, $8^{\circ} 27^{\prime} 5^{\prime \prime E}, 450 \mathrm{~m}$ a.s.I.). Each open top chamber had movable glass roofs closing automatically at the onset of rain fall. Three treatments were applied: drought and re-watering (D), air warming (AW) and their combination (AWD) as well as control (CO). The treatments were obtained by adjusting the aperture of the movable glass side walls of the open-top chambers (for temperature) and

125 interrupting the irrigation (for drought). Air temperature outside and inside the chambers were measured at $120 \mathrm{~cm}$ height with shaded EL-USB-2 data loggers (Lascar Electronics Ltd., UK) and development of soil drought was controlled by weekly measurements of volumetric soil water content at $62 \mathrm{~cm}$ depth (TDR 100; Campbell Scientific Inc, USA).

For intra-annual growth and wood anatomical analyses, the following Swiss provenances were

130 chosen for each species: $Q$. robur Tägerwilen (47³8' N, 908' E; 510 m a.s.l.; mesic site), $Q$. petraea Corcelles ( $46^{\circ} 51^{\prime}$ N, $6^{\circ} 41^{\prime}$ E; 550 m a.s.l.; mesic site) and Q. pubescens Leuk (46¹8' $\mathrm{N}, 7^{\circ} 38^{\prime} \mathrm{E} ; 720 \mathrm{~m}$ a.s.I.; dry site). Four saplings per provenance and treatment, in total 48 saplings, have been sampled. The dendrometric characteristics of the selected saplings at the end of the experiment are summarized in Table 1. 


\section{Growth conditions 2009}

Differences in diurnal temperature relative to the control CO were $+1.16,+0.96,+2.04{ }^{\circ} \mathrm{C}$ for AW, D and AWD, with peaks during the summer months (June, July, August) of up to $3^{\circ} \mathrm{C}$ for AWD (Fig. 1c). The drought treatments in 2009 (D and AWD) lasted from April to August, but were interrupted by short rewatering at July $1^{\text {st }}$ and at August $21^{\text {st }}$, when predawn leaf water

140 potential in AWD was reaching values around $-3 \mathrm{MPa}$ and $-4 \mathrm{MPa}$, respectively. Pre-drawn leaf water potential was biweekly measured for each treatment on 1 leaf per tree with a pressure chamber (M 600, Mosler Tech Support, Berlin, Germany). The seasonal profiles of the leaf water potential show that both drought periods lasted for 1.5 months with progressively increasing intensity (Fig. 1d). Drought level was reaching minima of -3.65 and $-4.00 \mathrm{MPa}$ in D

145 and AWD, while it never reaches value below $-0.5 \mathrm{MPa}$ in $\mathrm{CO}$ and $\mathrm{AW}$.

Leaf net photosynthesis $\left(A_{n e t}\right)$ was measured on recently expanded mature leaves using a portable gas-exchange system (Li-6400; Li-cor Inc., Lincoln, NE, USA). Measurements were taken before both re-watering events on three leaves per tree (Table 2).

\section{Pinning, preparation of microsections and ring-width development}

150 To monitor the dynamic of annual ring formation we applied the pinning method (Seo et al., 2007). The pinning consists in causing wound-reaction marks in the annual ring by using a pin briefly inserted at known dates into the stem cambium and to retrospectively use these marks in wood to reconstruct the position of the ring formation at pinning dates. Eleven pinning dates (P1 to P11) were selected in order to cover the whole 2009 growing season. The pinning dates performed throughout the season are indicated in Fig. 1b. Pinnings were performed in a spiral along the stem from $20 \mathrm{~cm}$ height upwards every $5 \mathrm{~cm}$ distance and pinning points marked on the bark. At the end of the growing season, the trees were cut and stems collected for the preparation of micro-sections at pinning positions. Thin micro-sections (thickness of $20 \mu \mathrm{m}$ ) of pinning marks and on a cross-section free of pinning reaction at $10 \mathrm{~cm}$ stem height (see

160 example in Fig. 1a) were obtained using a sliding microtome (Reichert, Germany), stained with safranin (1\%) and astrablue (2\%), dehydrated with ethanol (70, 95 and 100\%) and xylol, and fixed on microscope slides with Canada balsam. 
Images of the pinning microsections (P1 to $\mathrm{P} 11)$ were taken using a digital video camera (ColorView III, Soft Imaging System, Germany) connected to a transmitted light microscope 165 (Olympus BX41, Japan) with a 100x magnification and a resolution of $300 \mathrm{dpi}$. Since the field of view through the objective was not large enough to cover the entire tangential width of the ring surface, adjacent images from the same annual ring were merged together (Adobe Photoshop Elements 2.0).

The intra-annual increment over the season was measured on pinning images as the distance

170 between the previous tree-ring border and the last formed cell at time of the pinning (last cells with a secondary wall below the wound, (Seo et al., 2007)). Measurement of intra-annual ringwidth increments were made on both sides of the pin entry and averaged. The relative increment, giving the percentage of the entire growth ring formed until the pinning date, was calculated as a proportion of the measured intra-annual increment on the total ring width.

\section{Anatomical analysis}

Cellular anatomical characteristics of wood tissue (vessels, parenchyma and fibers) were measured on the pinning-free samples (P0) to avoid potential bias due to the wound reactions. Information about intra-annual increment has been reported into the new images to distinguish between timing of formation. Anatomical measurements have been grouped into three

180 periods, i.e., during first dry period (Period 1, from P1 to P7), from rewatering to second dry period (Period 2, from P8 to P9) and after second rewatering (Period 3, from P10 to P11). Measurements of cell anatomical characteristics were performed using image analysis. Images were taken with the same devices as for the pinning images, but with different magnification, depending on the features to be measured (40x for vessels, $100 \mathrm{x}$ for

185 parenchyma and 200x for fibers).

Vessels anatomical measurements have been performed on the ring cross-section surface covered by a $30^{\circ}$ stem circular angle using the image analysis software (Image Pro Plus, Media Cybernetics, Silver Spring, MD, USA). Vessel lumina were automatically recognized using the function for "bright object recognition" using filters to exclude vessel lumina smaller

190 than $200 \mu \mathrm{m}^{2}$. Manual correction was performed by object miss-recognition. For each object 
the vessel lumen area, vessel mean radius, and the radial position in the ring was measured. Sums for mean vessel area (MVA) and for conductivity (Cond, calculated according to the Hagen-Poiseuille law as the sum of the forth power of each vessel mean radius) per circular angle (i.e., divided by the measured stem circular angle) were finally calculated for each

195 species, treatment, and period of growth (Period 1 to 3 ).

The characterization of parenchyma cells was then performed by counting the number of parenchyma cells (excluding rays cells) on a radial band (minimal width $106 \mu \mathrm{m}$, maximal width $504 \mu \mathrm{m}$ ) of the ring and finally density of parenchyma cells per surface (PD) was calculated for each species, treatment, and period of growth. Counting and relative radial position of each cell in the ring was performed using the manual measurement tool of the software Image Pro Plus.

Finally, to evaluate the effect of drought on fiber cells (Fig. 1a), per each tree the radial diameter of a sequence of 14 fiber cells along 5 radial files ( 7 before and 7 after the first rewatering on July $1^{\text {st }}$ ) have been measured using the Image Pro Plus manual measurement

205 tool. Results have been grouped and averaged per species and treatment.

\section{Results}

\section{Growth}

The three consecutive experimental growing seasons under different climate treatments have

210 significantly affected the whole tree growth of the saplings (Table 1). Differences to the control (CO) were particularly strong for both drought treatments (D and AWD). All growth related parameters except root length (i.e., sapling height, sapling stem diameter, and leave surface area) showed a reduction between $31 \%$ and $54 \%$ depending on the parameter and the species considered. In general $Q$. robur was the most sensitive species to drought, while $Q$. petraea and Q. pubescens showed proportionally less growth reduction. In contrast to drought, air warming (AW) alone seemed to slightly promote growth in comparison to the control saplings although there was no consistent warming effect among species and analyzed 
parameters. The observed growth responses to drought were well reflected by measurements of net photosynthesis $\left(A_{N}\right.$, Table 2$)$ which were strongly reduced in both drought treatments in

220 a species-dependent manner with $Q$. robur being more sensitive than $Q$. petraea and $Q$. pubescens.

We observed increasing differences in radial growth of the annual ring 2009 between the treatments in coincidence of the pinning P5 (May $18^{\text {th }}$ ) and P6 (June $2^{\text {nd }}$ ) (Fig. 2), when the leaf water potential of drought-exposed saplings (D and AWD) dropped below <-1MPa (Fig.

$2251 \mathrm{~d}$ ). The radial growth of the drought-exposed saplings in all species continued to be strongly reduced in comparison to the control and the not-drought-limited treatment (AW), even after rewatering. Over the entire growing season 2009 the final reduction in ring width in comparison to the control was $59 \%$ (Qro), 66\% (Qpe) and 60\% (Qpu) for D and 74\%, 57\% and 77\% for AWD. In some drought exposed saplings we observed an earlier stop in radial growth (no

230 growth increment in Period 3). The reduction was stronger for Q. robur and less pronounced for $Q$. petraea than $Q$ pubescens. In contrast air warming (AW) slightly modified radial growth with changes of $+19 \%$ (Qro), $+1 \%$ (Qpe) and -10\% (Qpu) in comparison to the control saplings.

\section{Wood anatomy and conductivity}

Results obtained from wood anatomical measurements displayed a very large variability

235 among saplings and treatments. Thus it was important to standardize the results relative to tree size (i.e., for vessels anatomical measurements) or to surface or to the ring portion considered (i.e., for the quantification of the parenchyma cells). In general, responses observed at the anatomical level reflected the differences observed in whole tree growth, whereby differences relative to the control became apparent only for the drought-exposed

240 saplings ( $D$ and AWD). The distribution of vessel size classes for total vessel area and conductivity (Fig. 3 and 4) clearly indicated that drought-exposed seedlings produced fewer vessels in general, and in particular the larger vessels were smaller. The average vessel lumen area of the five largest measured vessels in $Q$. petraea was reduced by $52 \%$ in both drought treatments compared to the five largest vessels of the control. This reduction of the 
for $Q$. robur and $Q$. pubescens, respectively. However, In terms of average size changes in total vessel area, the droughts treatments (D and AWD) causes a strong reduction for all the species (ranging from $-44 \%$ to $-68 \%$ ), except for the drought treatment in Q. pubescens which by reduces only $15 \%$ (Fig. 3). Similar results are observed for the total potential conductivity,

250 the reduction of drought exposed saplings (D) in comparison to the control (CO) was -64\% for Q. robur, and -68\% for $Q$. petraea, while for $Q$. pubescens it remained almost unchanged (15\%, Fig. 4). Moreover, due to the limited growth recovery after drought, the number of vessels produced after rewatering was also strongly reduced, especially for the Period 3.

Differences in response to drought were also observed in the density of parenchyma cells

255 (Fig. 5), which tended to increase in drought-exposed trees (two factors ANOVA, $\mathrm{P}<0.1$ ), except for $Q$. pubescens. In general, in all the species the density of parenchyma cells tended to increase after the drought periods (Period 2 and 3 compared to 1). No differences between species were observed in the density over the total measured ring surface.

A clear anatomical mark of drought was observed in the size of the fiber cells. The radial

260 diameter of fiber cells produced under drought was significantly smaller than those produced in the control and air warming treatment or those formed after the rewatering (Fig. 6). After rewatering, usually the fiber diameter (around $4-5 \mu \mathrm{m}$ ) recovered quickly to almost the diameter of the control trees $(>10 \mu \mathrm{m})$.

\section{Discussion}

\section{Xylem structural adjustments to drought}

Plant strategies to control water status and resist drought are numerous (Maseda and Fernandez, 2006). A key component in drought tolerance of woody plants is to avoid the detrimental effect of embolism (Maherali et al., 2004). This can be achieved by resistance, redundancy and repair, which usually occur at conduction and efficiency costs (Pratt et al., 2008). The experiment conducted over three consecutive growing seasons clearly indicates that repeated periods of water shortage have induced significant anatomical adjustments in the xylem structure of the saplings of all the three oak species towards resistance and repair, 
which also had important impact on the growth performance. All drought-exposed saplings

275 have shown a significant radial growth reduction, a reduced vessels size with diminished conductivity and a slightly increased density of parenchyma cells.

Safety against the formation of embolism can be achieved through the avoidance of critical water potential or by building up a xylem tissue which is resistant to low water potential. The safety margin, i.e., the range between water potential at stomatal closure and cavitation, can

280 only be increased through structural modifications that reduce plant water losses with more efficient roots or less transpiring leaf area (Limousin et al., 2009) and/or by improving the xylem resistance to drought-induced embolism (Beikircher and Mayr, 2008). Since cavitation resistance mainly depends on xylem structure as arrangement, size, wall reinforcement and pit properties of conduits (Choat et al., 2008; Comstock and Sperry, 2000; Hacke and Jansen,

285 2009; Hacke and Sperry, 2001; Hacke et al., 2006; Sperry et al., 2006), xylem anatomical traits can be used to indirectly assess hydraulic safety. Many authors demonstrated the impact of drought on oak vessel characteristics (Barij et al., 2007; Campelo et al., 2010; Corcuera et al., 2004a; Corcuera et al., 2004b; Corcuera et al., 2006; De Micco et al., 2008; Eilmann et al., 2009; Galle et al., 2010; Levanic et al., 2011; Thomas et al., 2006), which are confirmed by the present study. Adjustments were usually oriented at reducing the size of the larger earlywood vessels which are more vulnerable to cavitation (Sperry, 2003). Since the 2009 earlywood vessels in oak have been build before June (Fonti and Garcìa-Gonzàlez, 2008), i.e., before the negative leaf water potential starts to decrease, the size adjustments are brought back to the drought occurred in the previous growing seasons (2007 and 2008). Size

295 differences to the control, which have been observed in the very few latewood vessels (formed after the first rewatering period 2 and 3), indicated that wood structural adjustments compensated for loss in conductivity, but were only possible in very limited magnitude during the year of stress (Arend and Fromm, 2007; Galle et al., 2010).

Repairing, by the refilling of embolized conduits, is a process that requires energy that 300 depends on the conversion of starch to sugar for aquaporin regulation and for the creation of an osmotic gradient within embolized conduits (Bucci et al., 2003; Salleo et al., 2009; Zwieniecki and Holbrook, 2009). In the entire 2009 annual ring, we observed an increase in 
the density of parenchyma cells containing starch in drought-exposed saplings (period P1 to P3) supporting the hypothesis of increased energy storage during drought to repair embolized vessels as soon as the conditions improve.

It is well known that a major direct effect of decreased water availability is diminished photosynthetic carbon fixation due to stomatal closure. Reduced growth has also been suggested as an acclimative feature for plant survival under stress (Rigling et al., 2002; Rigling et al., 2003; Weber et al., 2007), because it allows plants do redirect assimilates and energy

310 (otherwise used for shoot growth) for example to maintain respiration or to stimulate root growth and other protective adjustments against stress (McDowell, 2011). This supports the theory of carbon allocation that attributes the lowest priority to the stem growth under stress conditions (Waring, 1986). In this study it has been shown that water deficiency reduces photosynthetic carbon fixation and wood growth in stems. Furthermore water deficiency

315 induced the formation of smaller fiber cells and an earlyer stop of growth, especially if the drought occurs late in the growing season. Cell division and expansion are in fact directly inhibited by water stress (Abe and Nakai, 1999; Abe et al., 2003; Arend and Fromm 2007, Rossi et al., 2009) and in an extreme situation, plants might escape dehydration by shortening the length of the growing season (Eilmann et al., 2010).

\section{Intra-specific phenotypic plasticity and ecological behavior}

Differences between species for anatomical properties were first assessed in the absence of drought. $Q$. robur was different from the other species showing higher growth and a vessel size distribution characterized by larger and more numerous vessels. Under drought (D, AWD), Q. robur displayed a higher range of vessel phenotypic plasticity reducing size to

325 almost a comparable level of the other two species. This might explain the larger ecological range of this species. On mesic sites, $Q$. robur might be more competitive because it can fully exploit the more efficient water conducting system. This assumption is supported by the increased radial growth achieved under air warming conditions (AW) observed for only $Q$. robur. In contrast, the hydraulic safer species ( $Q$. petraea and $Q$. pubescens) might be excluded from humid places because of the limited efficiency in water transport and growth performance (Maseda and Fernandez, 2006). On drought prone sites it might be that $Q$. robur 
is approaching the critical threshold to survive under water scarcity due to the lower capacity of performing net photosynthesis under water scarcity as shown in the present study. Between the two other oak species which are considered to be more competitive under extreme drought, there was no clear difference in drought tolerance with respect to photosynthesis. Clear differences are however observed with respect to xylem anatomical plasticity. To further distinguish between these two species, a more extreme drought treatment would have likely been necessary. Our results support the hypothesis that $Q$. robur is hydraulically underbuilt for dry conditions, which predisposes the species to severe hydraulic constraints and subsequent mortality (Levanic et al., 2011). Q. pubescens, in comparison to Q. petraea, seems to be more drought tolerant since a strong reduction in conductivity is achieved only in the combined effect of drought and air warming (AWD).

\section{Conclusions}

345 In this work we assessed and compared major strategies of xylem hydraulic adjustments of three common oak species with differing drought tolerance growing under controlled experimental conditions during three consecutive years. We observed that acclimation to water scarcity of saplings exposed to drought and air warming is primarily oriented in increasing the safety against cavitation by developing a higher proportion of small and

350 hydraulically safer xylem vessels. All oak species showed a relative increase in parenchyma cell density to augment the capacity for actively repair cavitation. These adjustments imply reductions in growth performance and in the duration of the growing season.

Comparison between the species fostered our understanding of the relationship between the inter-specific xylem hydraulic plasticity and the ecological behavior to drought. Through a

355 broader range of phenotypic plasticity, principally characterized by the ability of producing larger vessel, $Q$. robur is more competitive under favorable growing conditions but at risk under severe exposition to drought. Although the results obtained from the present study performed on saplings seems to supply coherent results with observations of the ecological distributions of mature trees, future studies are needed to prove whether adult trees show similar growth responses. 


\section{Acknowledgments}

We thanks all the people that contributed to the realization of the "Querco experiment" and in particular the project-leader Madeleine S. Günthardt-Goerg. A special thank also to Loïc

365 Schneider for his precious contribution in preparing the micro-sections and Thomas Kuster for providing the data for Figure 1c.

This research was supported by grants of the VELUX Stiftung (project "Querco: Produktivität und Wasserhaushalt" $\mathrm{Nr}$ 489) and the Swiss National Foundation (project INTEGRAL $\# 121859)$. 


\section{References}

Abe, H. and Nakai, T. (1999) Effect of the water status within a tree on tracheid morphogenesis in Cryptomeria japonica D-Don. Trees-Structure and Function, 14(3), 124-129.

375 Abe, H., Nakai, T., Utsumi, Y., Kagawa, A. (2003) Temporal water deficit and wood formation in Cryptomeria japonica. Tree Physiology, 23(12), 859-863.

Allen, C.D., Macalady, A.K., Chenchouni, H., Bachelet, D., McDowell, N., Vennetier, M., Kitzberger, T., Rigling, A., Breshears, D.D., Hogg, E.H., Gonzalez, P., Fensham, R., Zhang, Z., Castro, J., Demidova, N., Lim, J.H., Allard, G., Running, S.W., Semerci, A., Cobb, N. (2010) A global overview of drought and heat-induced tree mortality reveals emerging climate change risks for forests. Forest Ecology and Management, 259(4), 660-684.

Arend, M. and Fromm, J. (2007) Seasonal change in the drought response of wood cell development in poplar. Tree Physiology, 27(7), 985-992.

385 Arend, M., Kuster, T., Gunthardt-Goerg, M.S., Dobbertin, M. (2011) Provenance-specific growth responses to drought and air warming in three European oak species (Quercus robur, Q.petraea and Q.pubescens). Tree Physiology, 31(3), 287-297.

Barij, N., Stokes, A., Bogaard, T., Van Beek, R. (2007) Does growing on a slope affect tree xylem structure and water relations? Tree Physiology, 27(5), 757-764.

390 Beikircher, B. and Mayr, S. (2008) The hydraulic architecture of Juniperus communis L. ssp communis: shrubs and trees compared. Plant Cell and Environment, 31(11), 1545-1556.

Bergman, K.O., Andersson, M., Milberg, P. (2011) Low pre-death growth rates of oak (Quercus robur L.)-Is oak death a long-term process induced by dry years? Annals of Forest Science, 68(1), 159-168.

Bucci, S.J., Scholz, F.G., Goldstein, G., Meinzer, F.C., Sternberg, L.D.L. (2003) Dynamic changes in hydraulic conductivity in petioles of two savanna tree species: factors and mechanisms contributing to the refilling of embolized vessels. Plant Cell and Environment, 26(10), 1633-1645.

400 Campelo, F., Nabais, C., Gutierrez, E., Freitas, H., Garcia-Gonzalez, I. (2010) Vessel features of Quercus ilex L. growing under Mediterranean climate have a better climatic signal than tree-ring width. Trees-Structure and Function, 24(3), 463470.

Cater, M. (2003) Pedunculate oak (Quercus robur L.) crown defoliation - Changes on permanent research plots. Ekologia-Bratislava, 22(4), 429-442.

Cater, M. and Batic, F. (2006) Groundwater and light conditions as factors in the survival of pedunculate oak (Quercus robur L.) seedlings. European Journal of Forest Research, 125(4), 419-426.

Choat, B., Cobb, A.R., Jansen, S. (2008) Structure and function of bordered pits: new discoveries and impacts on whole-plant hydraulic function. New Phytologist, 177(3), 608-625.

Cochard, H., Breda, N., Granier, A. (1996) Whole tree hydraulic conductance and water loss regulation in Quercus during drought: Evidence for stomatal control of embolism? Annales Des Sciences Forestieres, 53(2-3), 197-206.

415 Comstock, J.P. and Sperry, J.S. (2000) Theoretical considerations of optimal conduit length for water transport in vascular plants. New Phytologist, 148(2), 195-218.

Corcuera, L., Camarero, J.J., Gil-Pelegrin, E. (2004a) Effects of a severe drought on growth and wood anatomical properties of Quercus faginea. Iawa Journal, 25(2), 185-204. 
Corcuera, L., Camarero, J.J., Gil-Pelegrin, E. (2004b) Effects of a severe drought on Quercus ilex radial growth and xylem anatomy. Trees-Structure and Function, 18(1), 83-92.

Corcuera, L., Camarero, J.J., Siso, S., Gil-Pelegrin, E. (2006) Radial-growth and woodanatomical changes in overaged Quercus pyrenaica coppice stands: functional responses in a new Mediterranean landscape. Trees-Structure and Function, 20(1), 91-98.

De Micco, V., Aronne, G., Baas, P. (2008) Wood anatomy and hydraulic architecture of stems and twigs of some Mediterranean trees and shrubs along a mesic-xeric gradient. Trees-Structure and Function, 22(5), 643-655.

Domec, J.C., Lachenbruch, B., Meinzer, F.C., Woodruff, D.R., Warren, J.M., McCulloh, K.A. (2008) Maximum height in a conifer is associated with conflicting requirements for xylem design. Proceedings of the National Academy of Sciences of the United States of America, 105(33), 12069-12074.

Eilmann, B., Buchmann, N., Siegwolf, R., Saurer, M., Cherubini, P., Rigling, A. (2010) Fast response of Scots pine to improved water availability reflected in tree-ring width and delta 13C. Plant Cell and Environment, 33(8), 1351-1360.

Eilmann, B., Zweifel, R., Buchmann, N., Fonti, P., Rigling, A. (2009) Drought-induced adaptation of the xylem in Scots pine and pubescent oak. Tree Physiology, 29(8), 1011-1020.

440 Ewers, F.W., Ewers, J.M., Jacobsen, A.L., Lopez-Portillo, J. (2007) Vessel redundancy: Modeling safety in numbers. Iawa Journal, 28(4), 373-388.

Fonti, P. and Garcìa-Gonzàlez, I. (2008) Earlywood vessel size of oak as a potential proxy for spring precipitation in mesic sites. Journal of Biogeography, 35(12), 22492257.

445 Fonti, P., von Arx, G., Garcia-Gonzalez, I., Eilmann, B., Sass-Klaassen, U., Gartner, H., Eckstein, D. (2010) Studying global change through investigation of the plastic responses of xylem anatomy in tree rings. New Phytologist, 185(1), 42-53.

Galle, A., Esper, J., Feller, U., Ribas-Carbo, M., Fonti, P. (2010) Responses of wood anatomy and carbon isotope composition of Quercus pubescens saplings subjected to two consecutive years of summer drought. Annals of Forest Science, 67(8), -.

Gieger, T. and Thomas, F.M. (2005) Differential response of two Central-European oak species to single and combined stress factors. Trees-Structure and Function, 19(5), 607-618.

455 Hacke, U.G. and Jansen, S. (2009) Embolism resistance of three boreal conifer species varies with pit structure. New Phytologist, 182(3), 675-686.

Hacke, U.G. and Sperry, J.S. (2001) Functional and ecological xylem anatomy. Perspectives in Plant Ecology Evolution and Systematics, 4(2), 97-115.

Hacke, U.G., Sperry, J.S., Pockman, W.T., Davis, S.D., McCulloch, K.A. (2001) Trends in wood density and structure are linked to prevention of xylem implosion by negative pressure. Oecologia, 126(4), 457-461.

Hacke, U.G., Sperry, J.S., Wheeler, J.K., Castro, L. (2006) Scaling of angiosperm xylem structure with safety and efficiency. Tree Physiology, 26(6), 689-701.

Hopkins, W.G. and Hüner, N.P.A. (2008) Introduction to plant physiology John Wiley \& Sons, Hoboken, NJ.

IPCC. (2007) Climate change 2007: the physical science basis: contribution of Working Group I to the Fourth Assessment Report of the Intergovernmental Panel on Climate Change Cambridge University Press, Cambridge ; New York: pp.viii, 996 p.

470 Klein, T., Cohen, S., Yakir, D. (2011) Hydraulic adjustments underlying drought resistance of Pinus halepensis. Tree Physiology, 31(6), 637-648. 
Lambers, H., Chapin, F.S., Pons, T.L. (2008) Plant physiological ecology Springer New York, New York, NY: pp.604 S.

Levanic, T., Cater, M., McDowell, N.G. (2011) Associations between growth, wood anatomy, carbon isotope discrimination and mortality in a Quercus robur forest. Tree Physiology, 31(3), 298-308.

Limousin, J.M., Rambal, S., Ourcival, J.M., Rocheteau, A., Joffre, R., Rodriguez-Cortina, R. (2009) Long-term transpiration change with rainfall decline in a Mediterranean Quercus ilex forest. Global Change Biology, 15(9), 2163-2175.

Maherali, H. and DeLucia, E.H. (2000) Xylem conductivity and vulnerability to cavitation of ponderosa pine growing in contrasting climates. Tree Physiology, 20(13), 859-867.

Maherali, H., Pockman, W.T., Jackson, R.B. (2004) Adaptive variation in the vulnerability of woody plants to xylem cavitation. Ecology, 85(8), 2184-2199.

Martinez-Vilalta, J., Cochard, H., Mencuccini, M., Sterck, F., Herrero, A., Korhonen, J.F.J., Llorens, P., Nikinmaa, E., Nole, A., Poyatos, R., Ripullone, F., Sass-Klaassen, U., Zweifel, R. (2009) Hydraulic adjustment of Scots pine across Europe. New Phytologist, 184(2), 353-364.

Maseda, P.H. and Fernandez, R.J. (2006) Stay wet or else: three ways in which plants can adjust hydraulically to their environment. Journal of Experimental Botany, 57(15), 3963-3977.

McDowell, N., Pockman, W.T., Allen, C.D., Breshears, D.D., Cobb, N., Kolb, T., Plaut, J., Sperry, J., West, A., Williams, D.G., Yepez, E.A. (2008) Mechanisms of plant survival and mortality during drought: why do some plants survive while others succumb to drought? New Phytologist, 178(4), 719-739.

McDowell, N.G. (2011) Mechanisms Linking Drought, Hydraulics, Carbon Metabolism, and Vegetation Mortality. Plant Physiology, 155(3), 1051-1059.

Ponton, S., Dupouey, J.L., Breda, N., Dreyer, E. (2002) Comparison of water-use efficiency of seedlings from two sympatric oak species: genotype $\mathrm{x}$ environment

$500 \quad$ interactions. Tree Physiology, 22(6), 413-422.

Pratt, R.B., Jacobsen, A.L., North, G.B., Sack, L., Schenk, H.J. (2008) Plant hydraulics: new discoveries in the pipeline. New Phytologist, 179(3), 590-593.

Rigling, A., Braker, O., Schneiter, G., Schweingruber, F. (2002) Intra-annual tree-ring parameters indicating differences in drought stress of Pinus sylvestris forests within the Erico-Pinion in the Valais (Switzerland). Plant Ecology, 163(1), 105121.

Rigling, A., Bruhlhart, H., Braker, O.U., Forster, T., Schweingruber, F.H. (2003) Effects of irrigation on diameter growth and vertical resin duct production in Pinus sylvestris L. on dry sites in the central Alps, Switzerland. Forest Ecology and $510 \quad$ Management, 175(1-3), 285-296.

Rigling, A., Eilmann, B., Koechli, R., Dobbertin, M. (2010) Mistletoe-induced crown degradation in Scots pine in a xeric environment. Tree Physiology, 30(7), 845852.

Rossi, S., Simard, S., Rathgeber, C.B.K., Deslauriers, A., De Zan, C. (2009) Effects of a 20day-long dry period on cambial and apical meristem growth in Abies balsamea seedlings. Trees-Structure and Function, 23(1), 85-93.

Salleo, S., Trifilo, P., Esposito, S., Nardini, A., Lo Gullo, M.A. (2009) Starch-to-sugar conversion in wood parenchyma of field-growing Laurus nobilis plants: a component of the signal pathway for embolism repair? Functional Plant Biology, 36(9), 815-825.

Schenk, H.J., Espino, S., Goedhart, C.M., Nordenstahl, M., Cabrera, H.I.M., Jones, C.S. (2008) Hydraulic integration and shrub growth form linked across continental 
aridity gradients. Proceedings of the National Academy of Sciences of the United States of America, 105(32), 11248-11253.

525 Seo, J.-W., Eckstein, D., Schmitt, U. (2007) The pinning method: From pinning to data preparation. Dendrochronologia, 25(2), 79-86.

Siwecki, R. and Ufnalski, K. (1998) Review of oak stand decline with special reference to the role of drought in Poland. European Journal of Forest Pathology, 28(2), 99112.

530 Sperry, J.S. (2003) Evolution of water transport and xylem structure. International Journal of Plant Sciences, 164(3), S115-S127.

Sperry, J.S., Hacke, U.G., Pittermann, J. (2006) Size and function in conifer tracheids and angiosperm vessels. American Journal of Botany, 93(10), 1490-1500.

Sperry, J.S., Meinzer, F.C., McCulloh, K.A. (2008) Safety and efficiency conflicts in hydraulic architecture: scaling from tissues to trees. Plant Cell and Environment, 31(5), 632-645.

Sultan, S.E. (2000) Phenotypic plasticity for plant development, function and life history. Trends in Plant Science, 5(12), 537-542.

Thomas, F.M., Bartels, C., Gieger, T. (2006) Alterations in vessel size in twigs of Quercus robur and Q-petraea upon defoliation and consequences for water transport under drought. Iawa Journal, 27(4), 395-407.

Thomas, F.M., Blank, R., Hartmann, G. (2002) Abiotic and biotic factors and their interactions as causes of oak decline in Central Europe. Forest Pathology, 32(45), 277-307.

545 Tyree, M.T. and Cochard, H. (1996) Summer and winter embolism in oak: Impact on water relations. Annales Des Sciences Forestieres, 53(2-3), 173-180.

Tyree, M.T. and Ewers, F.W. (1991) The Hydraulic Architecture of Trees and Other Woody-Plants. New Phytologist, 119(3), 345-360.

Tyree, M.T. and Zimmermann, M.H. (2002) Xylem structure and the ascent of sap Springer, Berlin: pp.283 S.

Valladares, F., Gianoli, E., Gomez, J.M. (2007) Ecological limits to plant phenotypic plasticity. New Phytologist, 176(4), 749-763.

Vivin, P., Aussenac, G., Levy, G. (1993) Differences in Drought Resistance among 3 Deciduous Oak Species Grown in Large Boxes. Annales Des Sciences Forestieres,

$555 \quad \mathbf{5 0}(3), 221-233$.

Waring, R.H. (1986) Characteristics of Trees Predisposed to Die. In Studies in Environmental Science (T. Schneider, ed, Elsevier: pp 117-123.

Weber, P., Bugmann, H., Rigling, A. (2007) Radial growth responses to drought of Pinus sylvestris and Quercus pubescens in an inner-Alpine dry valley. Journal of

$560 \quad$ Vegetation Science, 18(6), 777-792.

Zimmermann, M.H. (1983) Xylem structure and the ascent of sap Springer, Berlin u.a.: pp.X, 143 p.

Zweifel, R., Rigling, A., Dobbertin, M. (2009) Species-specific stomatal response of trees to drought - a link to vegetation dynamics? Journal of Vegetation Science, 20(3),

565 442-454.

Zwieniecki, M.A. and Holbrook, N.M. (2009) Confronting Maxwell's demon: biophysics of xylem embolism repair. Trends in Plant Science, 14(10), 530-534.

Zwieniecki, M.A., Melcher, P.J., Feild, T.S., Holbrook, N.M. (2004) A potential role for xylem-phloem interactions in the hydraulic architecture of trees: effects of phloem girdling on xylem hydraulic conductance. Tree Physiology, 24(8), 911917. 


\section{$575 \quad$ Figures caption}

Fig. 1: Overview of the growing year 2009. a) Microscope image of a cross-section of the 2009 annual ring of a tree (Q. robur) subjected to drought and air warming (ring width $=575 \mu \mathrm{m}) . \mathrm{EV}=$ earlywood vessel, $\mathrm{LV}=$ latewood vessel, $\mathrm{P}=$ parenchyma cell,

580 F=fiber. b) Growth levels reached at pinning dates are indicated with dotted lines. After end of June an abrupt increase in the fiber size due to the rewatering is apparent. c) Temperature difference between the treatments inside the chamber and the measurement performed outside the chamber $\mathbf{d}$ ) mean predawn leaf water potential measured for each treatment. $\mathrm{CO}=$ Control, $\mathrm{AW}=$ Air warming, $\mathrm{D}=$ Drought, $585 \mathrm{AWD}=$ Drought and Air warming. Periods of growth are indicated on the $\mathrm{x}$-axis. Periods 1, 2 and 3 correspond to the time span with growth before and including first drought, before and including second drought and after the second drought respectively.

Fig. 2: Development of ring width at the pinning dates grouped by species and 590 treatment. $\mathrm{CO}=$ Control, $\mathrm{AW}=$ Air warming, $\mathrm{D}=$ Drought, $\mathrm{AWD}=$ Drought and Air warming. Mean $\pm S D ; n=4$.

Fig. 3: Total vessel lumen area grouped by treatment and species.

Standardization is performed by dividing total vessel area by the angular sector 595 considered. Bars indicate results for vessel lumen area grouped in classes of 2000 $\mu \mathrm{m}^{2}$. Periods correspond to the periods of growth with cells formed before and including first drought (Period 1, light grey), before and including second drought (Period 2, grey) and after the second drought (Period 3, dark grey), respectively. Values in the boxes indicate the percentage reduction of the average total vessel 600 lumen area in comparison to the control. 
Fig. 4: Total conductivity grouped by treatment and species. Standardization is performed by dividing total conductivity by the angular sector considered. Bars indicate results for conductivity grouped in classes of $2000 \mu \mathrm{m}^{2}$. Periods correspond

605 to the periods of growth with cells formed before and including first drought (Period 1, light grey), before and including second drought (Period 2, grey) and after the second drought (Period 3, dark grey), respectively. Values in the boxes indicate the percentage reduction of the average total conductivity in comparison to the control.

Fig. 5: Density of parenchyma cells [number $\left./ \mu^{2}\right]$, grouped by species, treatment and period of growth. Periods correspond to the periods of growth with vessels cells before and including first drought (Period 1, light grey), before and including second drought (Period 2, grey) and after the second drought (Period 3, 615 dark grey), and for the whole ring (Total, black), respectively. Mean $\pm S D, n=4$.

Fig. 6: Radial diameter $[\mu \mathrm{m}]$ of fiber cells measured along radial file. Cell position -7 to -1 are cells built before the end of first drought and 1 to 7 are cells build after the subsequent re-watering on July 1 st. Results are shown

620 grouped by species and treatment. $\mathrm{CO}=\mathrm{Control}, \mathrm{AW}=$ Air warming, $\mathrm{D}=$ Drought, $A W D=$ Drought and Air warming. Mean $\pm S D$. 
Figure 1

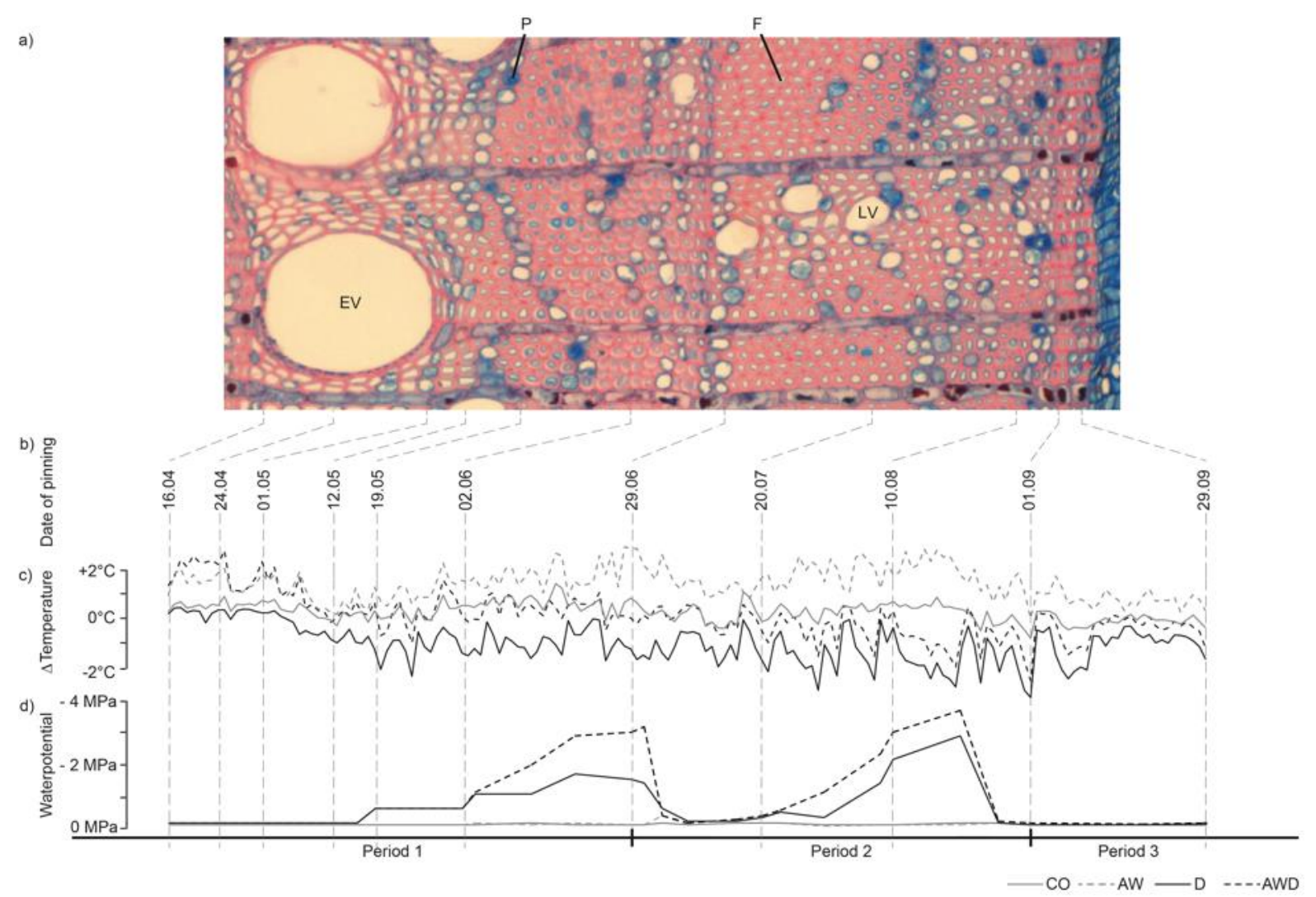


Figure 2

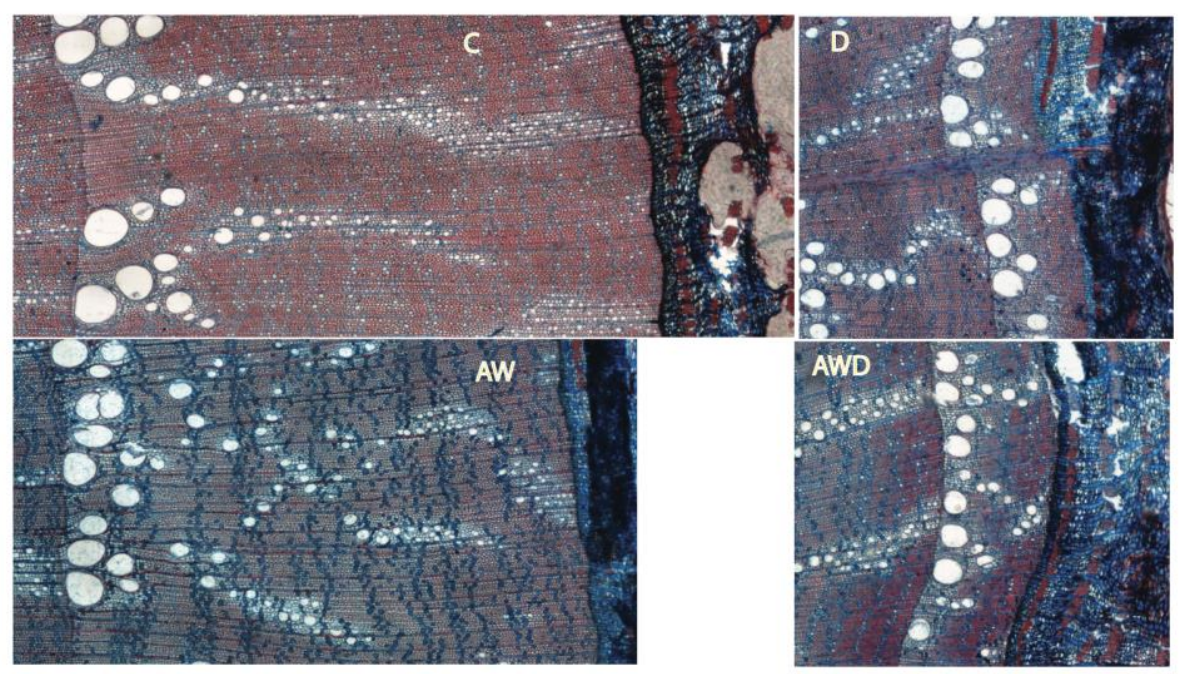


Figure 3

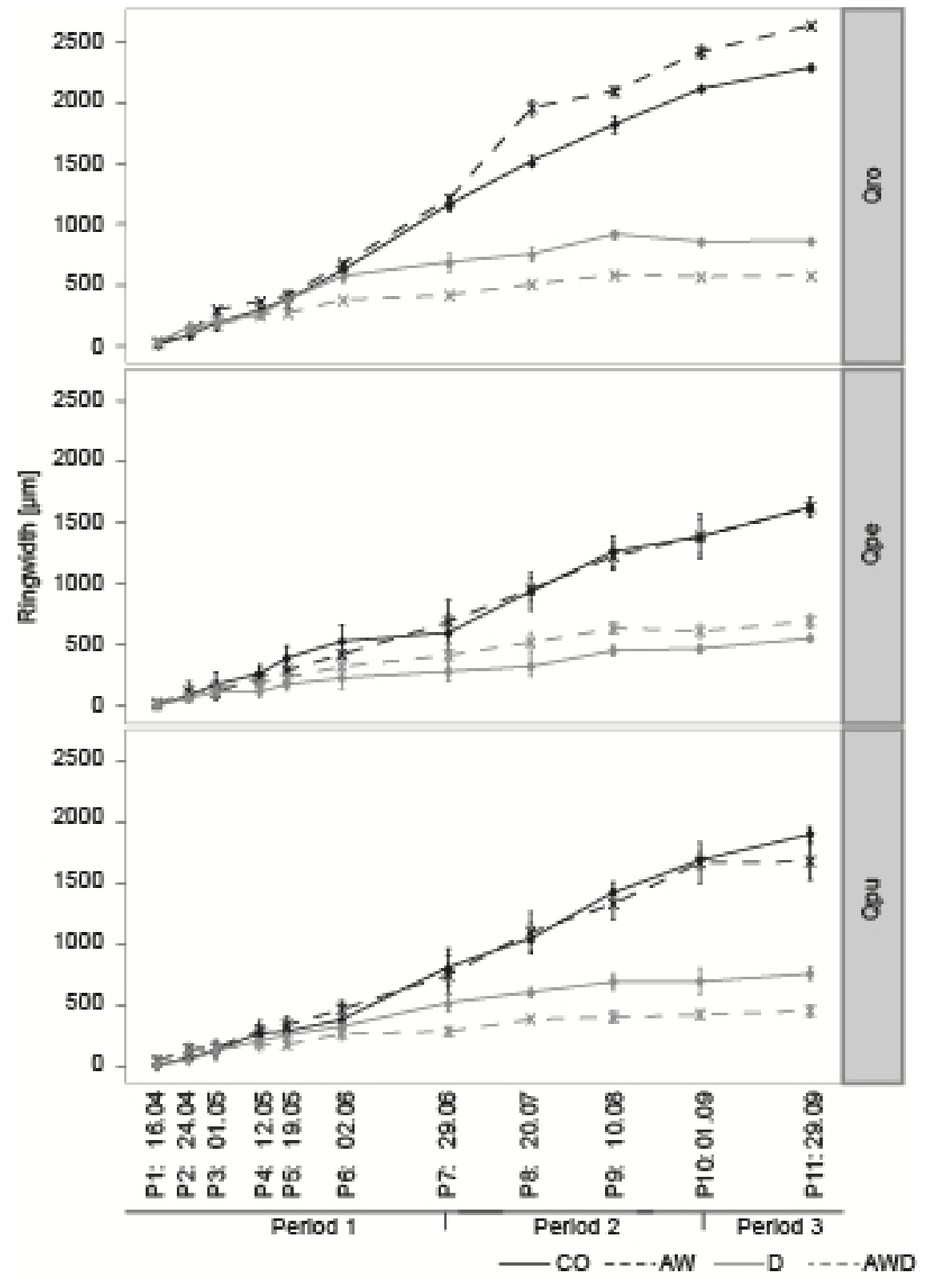


Figure 4

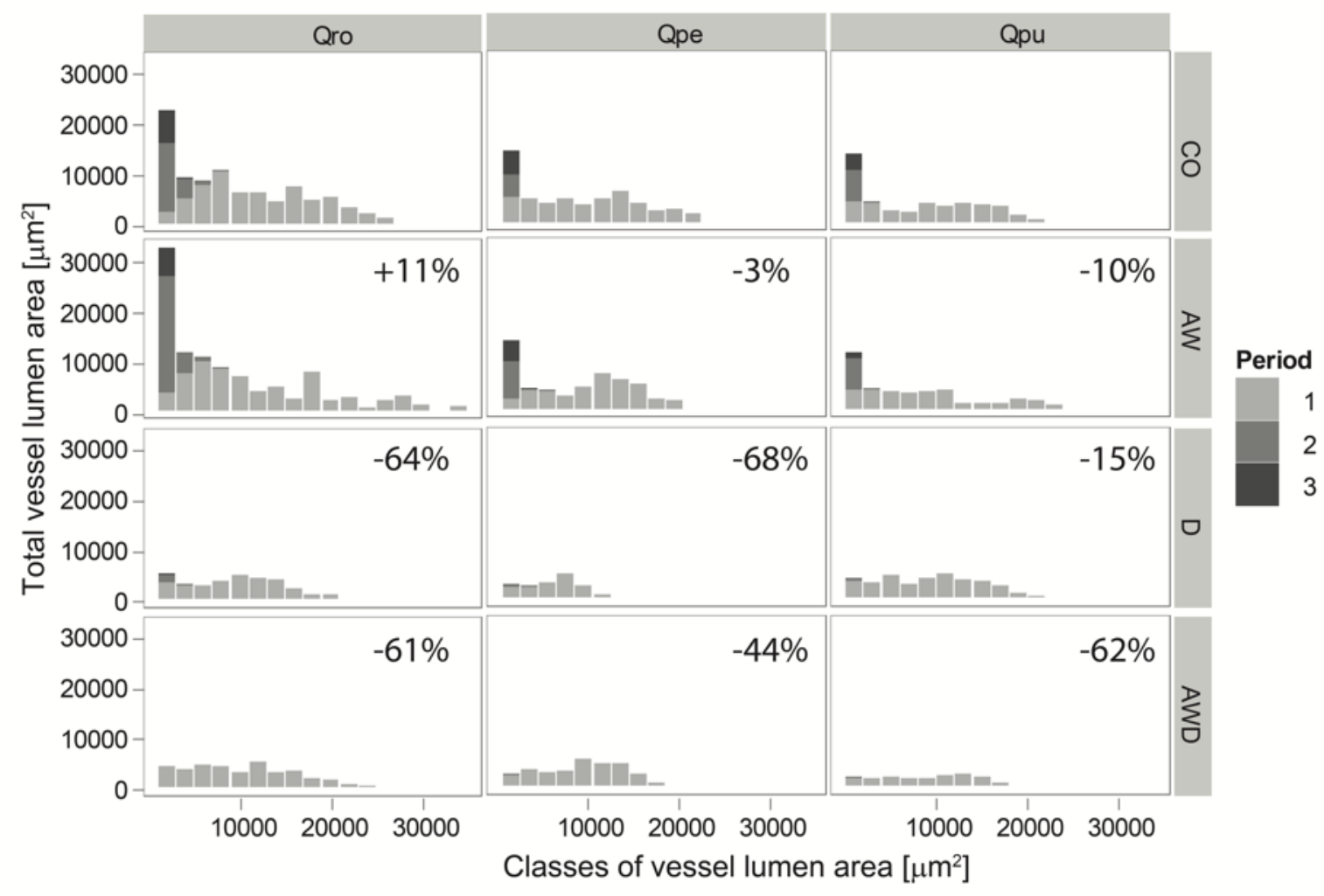


635 Figure 5

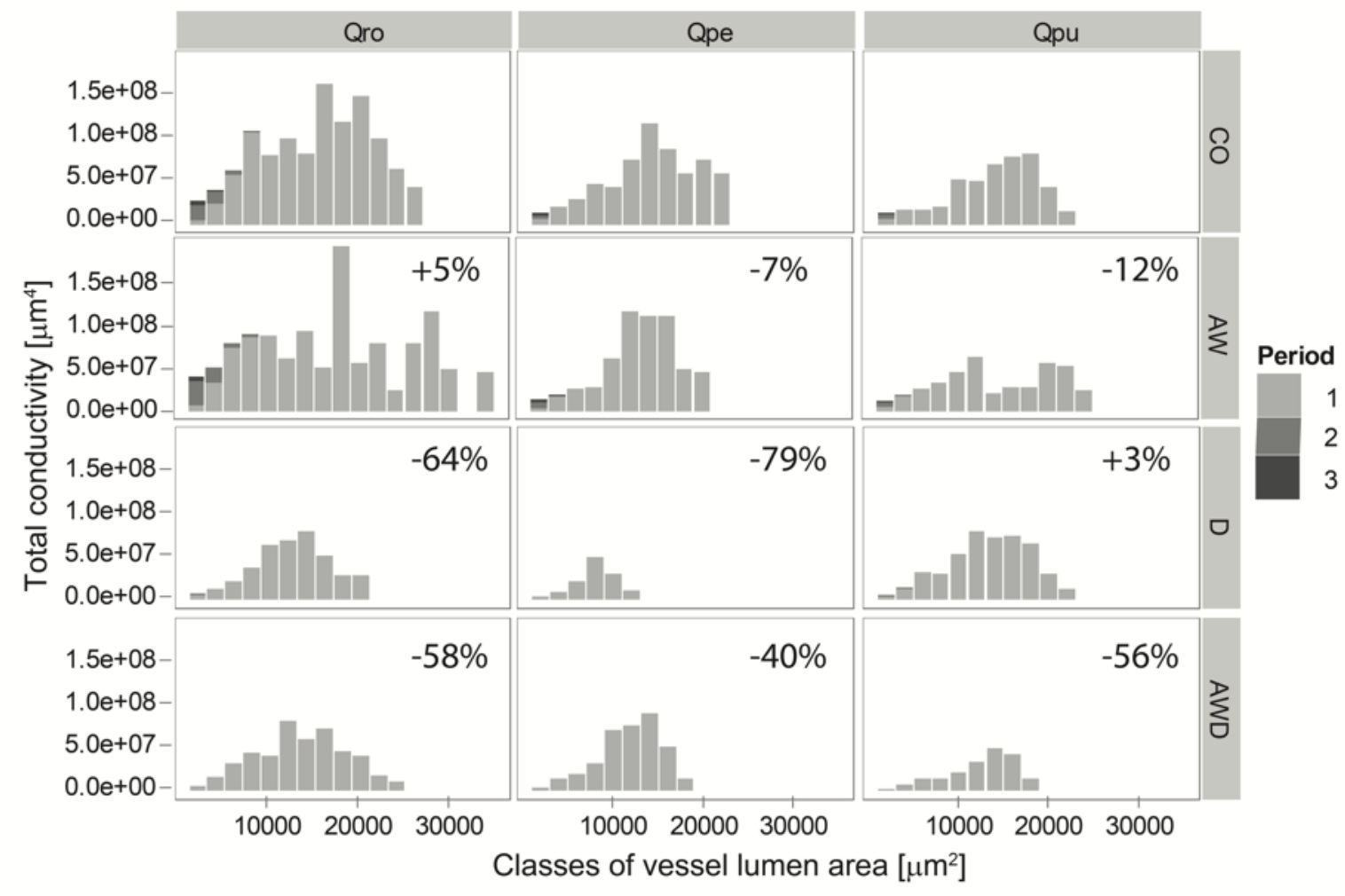


Figure 6

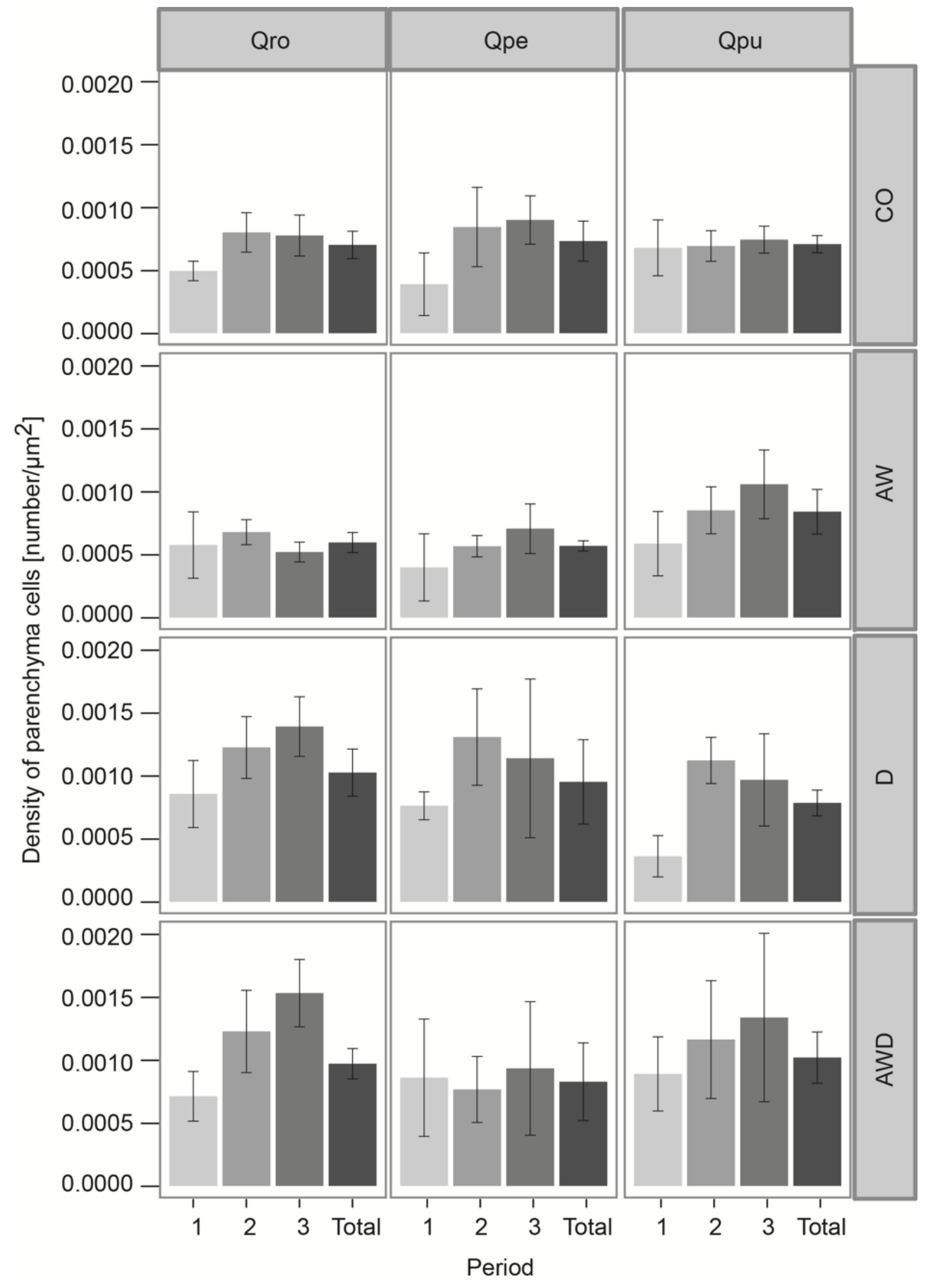


Figure 7

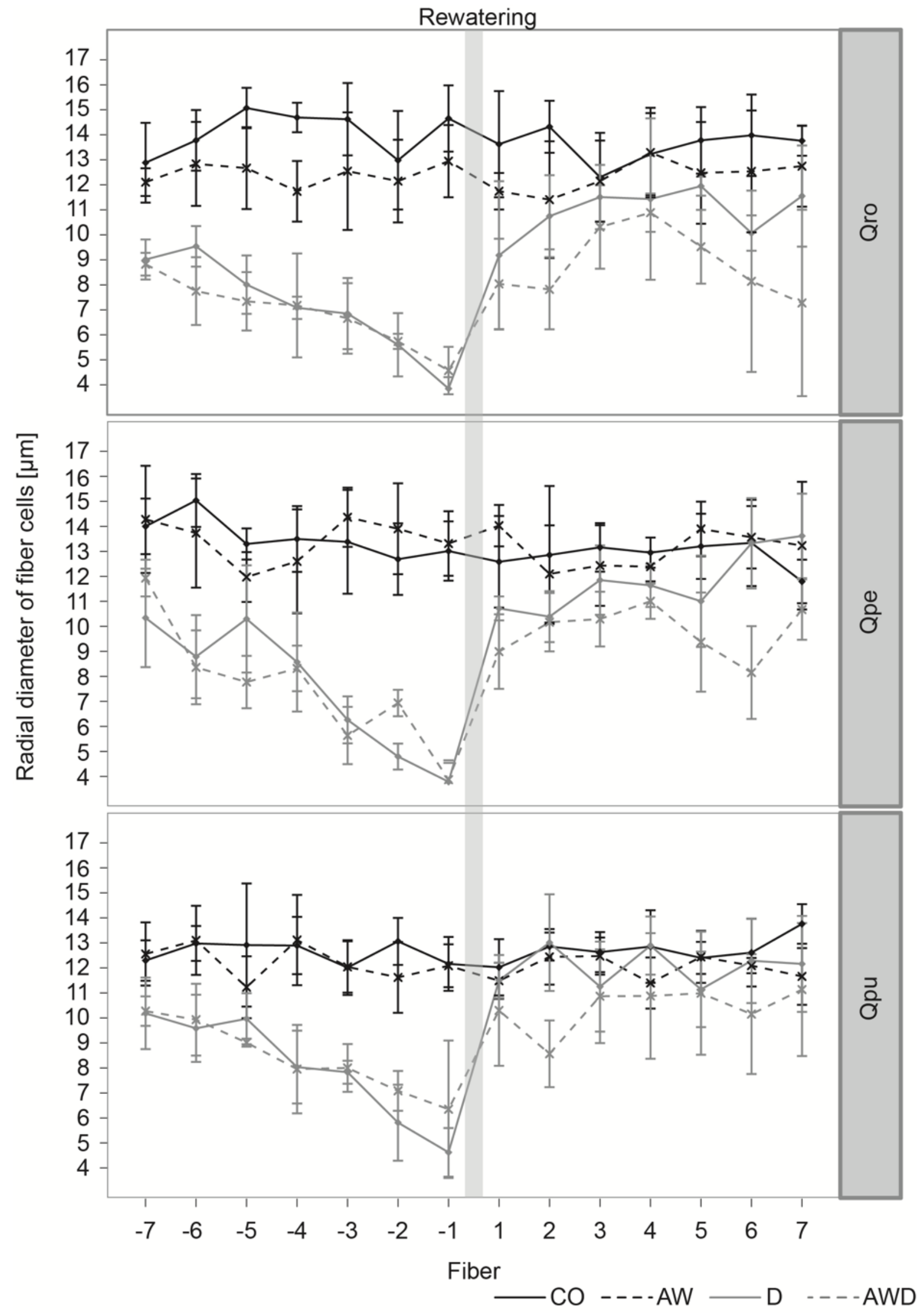

